\title{
Farming-Biodiversity Segregation or Integration? Revisiting Land Sparing versus Land Sharing Debate
}

\author{
Fernando F. Goulart*, Sonia Carvalho-Ribeiro, Britaldo Soares-Filho \\ Centro de Sensoriamento Remoto, Mestrado em Análise e Modelagem de Sistemas Ambientais, Departamento \\ de Cartografia, Instituto de Geociências, Universidade Federal de Minas Gerais, Belo Horizonte, Brazil \\ Email: "goulart.ff@gmail.com
}

Received 7 April 2016; accepted 10 June 2016; published 13 June 2016

Copyright (C) 2016 by authors and Scientific Research Publishing Inc.

This work is licensed under the Creative Commons Attribution International License (CC BY). http://creativecommons.org/licenses/by/4.0/

c) (7) Open Access

\begin{abstract}
Land Sparing (LSP) was proposed to spatially segregate biodiversity and production in order to maximize both, while Land Sharing (LSH) defenders posit that farming and nature integration is preferable, through eco-agriculture and low-input systems. Based on a multidisciplinary review on historical land-use data, ecological aspects, agricultural production potential, economic and food security topics, we summarize LSP/LSH major findings and caveats. Although LSH still has to address some issues, LSP relies on a series of assumptions that are not supported by data, particularly regarding the positive effects of intensification on agriculture expansion. Furthermore, we developed conceptual models to theoretically predict the responses of biodiversity and ecosystems services in dynamic landscapes with different natural habitat proportions and different intensification levels on the farmed areas. Agriculture intensification may expand farmland reducing habitat area fostering population declines at the "natural" patches (via habitat reduction and decreasing species intra patch flux through the matrix), as well as at the farm site by direct effect of intensification (heterogeneity reduction and pesticide use), leading to a species extinction and ecosystems services loss. This multiple negative effect of agriculture intensification is worsening in regions where habitat proportion is below $30 \%$, such as in many tropical biodiversity hotspots, making LSH a much safer strategy for conservation and food security.
\end{abstract}

\section{Keywords}

Agriculture Intensification, Biodiversity Conservation, Forest Transition, Food Security, Jevons Paradox, Tropics

\footnotetext{
${ }^{*}$ Corresponding author.
}

How to cite this paper: Goulart, F.F., Carvalho-Ribeiro, S. and Soares-Filho, B. (2016) Farming-Biodiversity Segregation or Integration? Revisiting Land Sparing versus Land Sharing Debate. Journal of Environmental Protection, 7, 1016-1032. 


\section{Introduction}

Reconciling food security with conserving biodiversity is of utmost importance, but a difficult task. Two opposing strategies have emerged in the ecological and agriculturalist literature to address this challenge: Land Sparing (LSP) and Land Sharing (LSH). Land Sparing Hypothesis (LSP) is based on the idea that greater yields driven by technological land intensification could provide more food and still spare natural areas from being converted to agriculture [1]-[3]. On the other hand, Land Sharing Hypothesis (LSH) is underpinned by the evidences that non-intensive agricultural, biodiversity-friendly, and ecosystem-preserving agricultural systems (such as agroforestry) should be pursued to balance conservation with environmentally and socially sound agriculture [4]. LSH has proven effective for cases such as shade cocoa [5], shade coffee [6], home gardens [7] and organic farming [8] [9].

Given a fixed production target that can be meet by farming expansion or yield increase via agricultural intensification, LSP proponents posit that high-input systems decrease the need for farmland enlargement (yield driven Forest Transition), leaving more space for biodiversity protection. As gross yield is considered the major bottleneck for food security by this framework, LSP defenders suggest that agriculture intensification can reconcile food and farming [1] [2]. Additionally, LSP proponents assume that most species (especially species that are priority for conservation) follow a concave adjustment, declining steeply with the increasing of agriculture intensification [2] [3] [10] and intermediate levels of intensification have relatively low conservation potential [2].

On the contrary to LSP, LSH proponents see agriculture intensification as one of the major causes of water and air pollution, as well as depletion of ecosystems services from local to global scales [11]-[13]. For example, pesticides and nitrogen fertilizers are amongst the greatest cause of water contamination [14] [15]. Critiques on LSP concern the fact that there is a positive effect of yield increase on farmland expansion (Jevons Paradox Hypothesis) [16] [17]; the dynamic relationship among production and economic aspects (there is no fixed targeted yield); the high productivity of some non-intensive methods; the fact that significant biodiversity can be held in intermediate intensive systems; and the importance of social aspects that affects food security beyond gross yield [18]. In this light, non-intensive agricultural systems benefit ecosystems services, such as carbon storage, pollination and pest control [19]. Furthermore, non-intensive methods such as agroforestry systems may be more adapted to climatic change than mono-specific plantations [20].

The LSP-LSH debate has been very prominent in literature with nearly 829 papers published up to January 2016, as shown by an exploratory search in Science Direct (considering agronomic and biological sciences and both land sparing and land sharing terms). Despite of the flourishing of the LSP-LSH debate, there also has been a call for moving beyond the sharing vs. sparing divide [20] [21]. Some authors point out the need to go over the dichotomy highlighting that land sharing and sparing approaches are not mutually exclusive [22]-[24]. In a recent review Kremen [22] supports that the dichotomy of the land-sparing vs. land-sharing frameworks limits the realm of possibilities to only two, largely undesirable, options for conservation. Furthermore, many questions are still to be addressed in the sparing and sharing debate. Among of them are comprehension of the complex relationship among agriculture intensification, land use and ecological responses. One of the few studies to address such issue was carried by Green [2] in which the authors take some assumptions that were latter subjected to critiques [4].

In order to provide a critical and multidisciplinary review on the issues embed in the LSP LSH debate, we start by exploring broad trends in historical land use data (Section 2.1) highlighting the land use implications of the sharing vs. sparing debate. Relevant micro and macroeconomics arguments are then presented (Section 2.2). Next, we compare the different views of LSP and LSH on food security and agriculture production (Section 2.3). We also explore the ecological and ecosystem services topics that indicate which species tend to be favored by each strategy (Section 2.5). By associating the land-use and ecological findings, we developed conceptual models to understand ecological and ecosystems responses to dynamic landscapes with changing natural habitat proportion and changing intensification levels at the farmed area. Finally, based on the analysis, we aim at summing up evidence the debate nowadays supports as well as the needs for further research (Section 4).

\section{A Multidisciplinary View in the LSP vs LSH Debate}

\subsection{Historical Land Use}

LSP posits that increasing yields reduce farming area; hence agriculture intensification would reduce habitat loss 
[2]. The term "Forest Transition”, coined by Mather [25], whereby forest dynamics shift from contraction to expansion via yield increase, was redeemed to support land sparing driven by intensification. In fact, forests expanded in Europe after urbanization and agricultural industrialization [26]. This process also occurred in the southeast and northeast of USA in the 1900's [26] as agriculture shifted to prairies. Forest expansion also took place during the 1990s in developing countries such India, China, and Vietnam [27]. Nevertheless, Mather's "forest transition" considers as "forest" all types of forests (including forest plantation) regardless of the ecological constraints of silviculture.

Forests expand/contracts in particular regions while agriculture keeps advancing in other regions [28], such as central-west Brazil, where the increase Brazil soybeans exports in 282.9 percent in 2015 [29]. Thus, expansion in one region can be a result of exporting agriculture and its externalities elsewhere. Additionally, complex spatial processes such as deforestation leakage [30], the effect of forest protection on deforestation elsewhere, can mask Forest Transition process. For instance, protection of the Amazon led to an increase in deforestation in the Cerrado [31]. The idea that that both agriculture products can be produced in some places and be used to feed populations elsewhere, and so as forest protection/degradation in some locales may cause deforestation/regrowth displacement to other parts, makes Forest transition/Jevons particularly hard to assess.

Still, there are consistent evidences that in most places, agriculture intensification actually leads to increasing deforestation rates [16] contradicting the forest transition driven by yield increase. Rudel and colleagues have conducted a global assessment of farming area in related to yield variation from 1990 to 2005 [16]. Corn, rice, soybean, banana, sugar cane, cotton and potato crops have increased simultaneously yields and farming area, contradicting assumptions that yield improvement induces forest transition. By contrast, coffee and wheat followed the tradeoff between productivity and agricultural area following the LSP trends. In these few cases, in which farming decreased alongside increasing yields, the decrease was relatively small $(-4.3 \%$ for wheat and $-8.2 \%$ for coffee). In sum, large increase in farming area is often associated with yield increase for most crops. For example, soybeans increased by $21 \%$ while farming area increased by $63 \%$ in the last 15 years [16]. Globally, yields of main crops have increased by a quarter while farming area augmented by $8.3 \%$. Therefore, for most crops and most regions the LSP main assumption that agriculture intensification would reduce farming area together with habitat loss does not seems to hold.

Association between agriculture intensification and farm expansion or retraction depends on governance. Ceddia et al. [17] showed that governance and socioeconomics characteristics in place have deep effects on the occurrence of negative yield-forest loss relationships [17]. Conventional governance that accounts for corruption control, voice and accountability and rule of law, as defined by the World Bank [32] is positively correlated with agricultural expansion mediated by intensification. Thus, countries with conventional market-oriented governance face yield increase associated with agricultural area expansion (Jevons Paradox). However, yield increase leads to a smaller farm expansion rates in countries that accounted for high index of sustainable governance represented by two different indexes (Environmental Sustainability Index, www.yale.edu/esi, and Environmental Performance Index, $\underline{w w w . e p i . y a l e . e d u})$. Therefore, in the presence of environmental governance, yield increased may occur along with shrinking farmlands [17].

On the other hand, the relationship between LSH managements and farming area expansion/contraction remains unknown. Sporadic records suggest that LSH strategies, such as agroforestry, reduce habitat loss, as these systems provide food, fuel, timber and fiber fulfilling the needs of local populations, without demanding further deforestation [33]. In one of a remarkable example of ecoagriculture shift at country scale, Cuba has converted its once intensive fields into organic agriculture, managed through low input and agroecological methods (such as ecological pest control, biofertilizers, animal crop association and son on etc.) after losing the Soviet Union as its main trader. Simultaneously, forest cover in the country increased $40 \%$, which is the second largest proportional forest net growth in the recent decades worldwide [34]. Still there is a need for further studies to address the effects of non-intensive farming on biological diversity and habitat loss in different socio ecological contexts. Table 1 summarizes selected studies concerning the association between agriculture intensification, farmed area and deforestation.

\subsection{Economics}

Proponents of LSP often assume a fixed production target [2] [10]. According to neoclassical economic theory, food production and distribution follow a market demand/supply relationship. In this sense, the idea of a fixed 
Table 1. Empirical studies concerning the association between agriculture intensification, farmed area and forest change.

\begin{tabular}{|c|c|c|c|}
\hline Region/scale & Years & Main trends & References \\
\hline Denmark & 1800 ’s & $\begin{array}{l}\text { Technological advance and simultaneous change in land } \\
\text { tenure and forest management have decrease deforestation }\end{array}$ & [21] \\
\hline Switzerland and France & $\begin{array}{l}\text { Second half of 1900's } \\
\text { Mid 1900's }\end{array}$ & $\begin{array}{l}\text { Agriculture intensification, rural exodus and } \\
\text { farmland abandonment lead to forest recovery. } \\
\text { Additionally, changes in the } \\
\text { energy sector (from wood age to } \\
\text { fossil fuels) decreased logging. }\end{array}$ & [21] \\
\hline Southern of the USA & 1935 to 1975 & $\begin{array}{l}\text { Agriculture improvements in yield } \\
\text { associated with forest expansion. } \\
\text { Nevertheless, deforestation and } \\
\text { farm expansion occurred in the prairies, } \\
\text { showing that deforestation was } \\
\text { shifting towards the west }\end{array}$ & [21] \\
\hline China, India and Vietnam & 1990 & $\begin{array}{l}\text { Technification of agriculture, urbanization } \\
\text { and rural exodus occurred simultaneously, as } \\
\text { the decrease in deforestation changing } \\
\text { from deforestation to positive net gain. }\end{array}$ & [27] \\
\hline Ghana & 1975 to 2005 & $\begin{array}{l}\text { Bi-causal relationship between cocoa output and } \\
\text { deforestation, showing that increasing yields } \\
\text { leads to higher deforestation rates. }\end{array}$ & [36] \\
\hline North west Argentina & 1972 to 2001 & $\begin{array}{l}\text { Introduction of intensive high yield soybeans } \\
\text { plantation increased deforestation. }\end{array}$ & [37] \\
\hline Mexico & 1976 to 2000 & $\begin{array}{l}\text { Market-based and urban oriented economy and } \\
\text { agriculture intensification of commodity } \\
\text { production was associated to deforestation. }\end{array}$ & [38] \\
\hline Cuba & 1990 to 2000 & $\begin{array}{l}\text { The country has increased its forest cover by } 40 \% \\
\text { while simultaneously decreasing agriculture } \\
\text { output and agriculture intensification degree. }\end{array}$ & [34] \\
\hline South America & 1970 to 2001 & $\begin{array}{l}\text { Effects of agriculture intensification on farming expansion } \\
\text { depend on the quality and type of governance. Countries } \\
\text { with a market oriented governance show positive } \\
\text { relationship of intensification on farmland expansion, } \\
\text { while in countries with high quality environmental } \\
\text { governance agriculture intensification is possible } \\
\text { without further agriculture enlargement }\end{array}$ & [17] \\
\hline World & 1970 to 2005 & $\begin{array}{l}\text { Agriculture intensification of ten most important } \\
\text { crops was not correlated with crop land decrease or } \\
\text { stasis. In many situations, agriculture intensification } \\
\text { actually increased agricultural area. }\end{array}$ & [16] \\
\hline World & 1980 to 2000 & $\begin{array}{l}\text { Weak tendency of staple crops yield increase } \\
\text { associated with reducing farmland expansion in } \\
\text { developing countries and no evidence at all for } \\
\text { developed countries. Areas of natural forests were } \\
\text { smaller in countries where yield increased more. }\end{array}$ & [39] \\
\hline
\end{tabular}

production target has several constraints [35]. Agribusiness aims at maximizing profits and achieving competitive advantages. Production is a matter of supply/demand dynamics, in which less attention is given to food security or conservation. Price elasticity, governmental subsides to agriculture and land-tenure make the concept "targeted production" used by Green and colleagues [2] unrealistic. Additionally, more production due to increased yields would, among other factors, decrease prices and thus decrease profit margins. Paradoxically this approach may expand the cultivated area, especially if land prices are low and agricultural expansion is feasible [40]. In the Amazon, for example, the rapid increase in soy rents and cheap land prices may displace ranchers, 
who sell their lands, to new forest frontiers [40] [41].

In Marxist economic theory, food security is a consequence of social dynamics, land availability, and labor exploitation [42]. Scarcity or availability of food is consequence of power, labor exploitation, and controls over the means of production. Agricultural intensification leads to a greater dependence of external inputs (fertilizers, pesticide, machinery, and so on). In light of Marxist economic theory, a market based LSP strategy is insufficient to address food security [43], because it aggravates economic disparities, land concentration, and thus agribusiness oligopoly [43].

Ecological microeconomics, the science used to value ecosystems services and how biodiversity loss impairs natural capital, argues that LSH takes into account externalities and the economic value of ecological services, whereas LSP practically disregard them [11] [12]. According to macro-economic perspectives, LSP assumes, at least indirectly, the Kuznets curve [44]. This curve describes a behavior between economic growth (generally measured by GDP) and environmental conservation that follows an inverted-U shape, so that when a country or a community increases income, there is a decline in biodiversity because of demographic growth and increasing consumption. This increase reaches a peak and then declines because more advanced technology fosters greener and more efficient practices. This is predicted by LSP and may have some applications to northern countries. Nevertheless, at the global scale, increasing income is often associated with nature degradation [44]. One explanation for this lies on the Jevon's Paradox theory, which describes a rebound effect in resource use efficiency and consumption. Willian Stanley Jevon, a British economist of the 18th century, stated that efficiency increase in coal consumption would not lead to less resource consumption, but in fact, increase coal use [45]. As shown in the previous section, LSP is based on the idea that agriculture efficiency will reduce resource consumption (Forest transition driven by agriculture intensification), while LSH recognize that efficiency and consumption might have positive associations as predicted by the Jevons Paradox.

Economic policies such as credit to agriculture, and certification of farming products can greatly alter the agroecological and intensive farming profitability. Billions of governmental expenditure goes to agriculture on financial incentives every year. Green et al. [2] criticizes the large amount of money spent in agroecological schemes in Europe. We believe that this view is flawed, as most of the agriculture incentives goes to intensive agriculture rather than non-intensive ones. For example, during 2015 the Brazilian government spent 45 billion dollars in agriculture incentives (intensive and non-intensive), while only 720 million dollars is devoted to low carbon and non-intensive agriculture [46]. These uneven economic incentives for different modes of agriculture lead to unfair competition among non-intensive and intensive methods, greatly favoring the second one in local and international markets.

Another economic aspect that changes the agriculture profitability is certification. Organic, shade-coffee, biodiversity-friendly farming and fair trade are example of such. Via certification, consumers have access social and environmental friendly products, even if these cost more than conventional counterparts [47]. Certified organic farming has become one of the fastest growing segments of US and Europe in the last years [48]. Certification benefits LSH practices aggregating economic value to its products, overcoming potential yield loss in situations which there is a yield penalty of non-intensive agriculture and increasing profits in situation in which there is no yield loss due to organic/agroforestry management.

\subsection{Agricultural Production and Food Security}

By and large, there appears to be a misunderstanding over the definitions of food security and agricultural production in the land-use debate arena [18] [49]. Global, national and regional food security means that a given nation should maximize production of agricultural goods on a per capita basis [50]. Household and individual food security also encompasses individual nutritional standards, including hygiene education, clean water and sanitation [50].

LSP is based on the idea that intensification increase food production [2] [3], while LSH suggests that nonintensive farming may be also productive [16] [51]. Early studies have found that average organic-non organic yield ratio for 26 crops is 0.9 , although more than half of milk products and beans had ratios graters than 1.0 [52]. Badgley et al. [53] compared yield trends among developing and developed countries to find that most food categories had yield ratios slightly $<0.1$ in developed countries, while developing ones had ratios $>0.1$. In turn, Seufert et al. [54] suggest that the overall yield of intensive methods is higher than that of the organics, although the organic/intensive yield ratio is again very context-dependent [54]. For fruits, this ratio is very close to 
one as predicted by LSH. Perennials and legumes, as well as staple crops, such as maize and soybeans, account for $\sim 0.9$ organic/intensive yields [54].

Family farming is by far the most common form of agriculture in the world. FAO [55] estimates that there are at least 570 million farms worldwide and that over $90 \%$ of them (over 500 million) are family farms. The vast majority of family farms are small and about $94 \%$ of farms worldwide have less than 5ha, and even a large part of those have less than 2 hectares [55]. One of the primary constraints in quantitative assessments is that small farms are frequently not detectable from official records and statistics. It is thus difficult to accurately quantify their number, distribution, production capacity and contribution to food availability (i.e. production). Small farms are regarded to produce more per land area and negative farm size-productivity relationship is long known by agriculturalists as well [56]. Among the advantages of small farming are the multiple crop benefits, better output composition (larger farms produces crops of lower prices than do smaller farms); higher irrigation efficiency due to small area and proximity agricultural land to farm steads; and labor quality and intensity (more labor per area). Small farms may also use more input per agricultural land, and resource use is more efficient in small individual or family agricultural areas [57]. Although many small farms are in fact more intensive than the large scale counterparts, LSH is generally associated to small subsistence agroecological methods, while LSP is described to agribusiness companies and large land owners. Therefore, size of farms is extremely important when it comes to economy livelihoods and food security.

Of particular interest to LSP and LSH debate is the view of the agricultural landscape as a system with inputs, outputs and externalities. Thus comparing outputs in isolation is not enough to distinguish the efficiency of intensive and non-intensive agriculture production. In general, intensive agriculture is associated with larger inputs and slightly more outputs [58], ensuing negative externalities. In turn, agro ecological management have lower inputs and lower outputs (although this is very context specific e.g. [52]-[54]) and results in positive ecological externalities [12]. The efficiency of an agro ecological system is thus frequently higher [58], whereas intensive agricultural management is generally lower. Therefore, not only production but also efficiency is important. Critical factors, such as water scarcity, economic and climate change risks, make efficiency, not productivity, central in managing the agricultural landscape system.

LSP often assumes that agriculture production/efficiency and food security are linearly correlated, a perspective often criticized by LSH [4]. The increasing use of agricultural land for producing biofuels [59] along with food scarcity, low health conditions for the poor, food waste and overconsumption make the relationship between agricultural production and food security complexly non-linear. Hence, not only increasing yields per capita, but also food accessibility has to be tackled to secure food especially for the poor.

Food waste has also a large impact on food security. Globally, around 30\% of the food is wasted [60]. Of this, $40 \%$ is lost in post-harvest procedures in under-developed countries and $40 \%$ is lost by retailers and consumers in industrialized countries [61]. Meat-based diets are also less efficient in energy terms than vegetarian diets [62]. Overconsumption is another problem, entailing health issues as well as decreases in food availability for others. Obesity, although historically associated to wealthy nations, is becoming a problem worldwide. Additionally, the expansion of biofuels or biomass production consumes large tracts of lands that could be used for growing crops, further increasing food insecurity [63].

Therefore, two basics gaps must be bridged to achieve individual and household food security: the potential and realized yield/efficiency gap (through more efficient agriculture) and the production-individual food security gap (which is related to non-food crops production, food access and distribution, consumption evenness and so on). The difference between achievable to realized yield is known as "yield gap" and has been long debated [64]-[66]. While some authors propose that intensification can fill this gap [67], others suggest that agroecological methods will better succeed [68]. At this regard, carefully planned resource-conserving agricultural systems may increase yields at the same time sequestering carbon and thus contributing to climate change mitigation [55]. Additionally, some non-intensive systems, as intensive farming systems [56], are below their productive potential, and can have yield improved without changing its sustainable characteristics [69]. The second gap refers to the part of agricultural production not effectively used to feed the hungry. Some countries may succeed in improving individual food security with low yield rates, while others have improved productivity and yet not solved hunger.

Hence, yield increase alone cannot guarantee food security because food security policies, health care, education, warfare and competition among edible and non-edible crops all together play a key role in hunger alleviation. Additionally, the food industry is one of the most sophisticated businesses with refined installed lobbies 
which act well beyond the reach of national governments [69]. Food industry lobbies often control international trading bodies challenging the ways in which agricultural production effectively is used to feed the hungry.

\subsection{Ecological Theories and Ecosystem Services}

LSP was largely influenced by island biogeography theory, while LSH builds upon metapopulation theory [4] [21]. The theory of island biogeography describes the equilibrium in species diversity as a function of size of patches of suitable habitat and distance of these patches from the largest patch (main land), given differential migration and extinction rates [70]. Therefore, the number of species in a given habitat island is a balance between the chances of the species becoming locally extinct (by anthropogenic or natural causes) and the chances of recolonization by individuals arriving from other habitat patches into a particular habitat island. On the other hand, proponents of the LSH framework focus on the importance of the ecological qualities of the landscape matrix in balancing local extinction rates according to the metapopulation dynamics. In this view, the landscape is a continuum [71] of habitat quality serving as a conduit or a barrier to dispersal, rather than a binary habitatnon habitat approach [4]. Metapopulation resembles the theory of island biogeography, although it is applied to population dynamics of a suite of local populations inhabiting a patchy landscape [72]. Each subpopulation has an extinction probability along with a probability of dispersing between patches (colonization rates). Further application of the metapopulation theory on complex heterogeneous landscapes, such as the Brazilian Cerrado, also corroborates LSH higher efficiency [73].

With respect to the relationship between biological and production parameters studies that point out for LSP superiority predict that most species (especially species that are priority for conservation) follow a concave adjustment declining steeply with the increasing of agriculture intensification. According to LSH defenders, in turn, intermediate agricultural management regimes can often conserve communities/species following a convex, inverted-U and null richness/abundance and agricultural intensification. Convex patterns predicts a slight decline at intermediate levels of intensification, inverted-U pattern suggest that species richness/abundance maximum is reached at medium levels of agricultural intensification/production, which can be predicted by intermediate disturbance theory [74]. A null model means that species are insensitive to agricultural intensification (Figure 1). Table 2 shows selected studies supporting these main patterns across different regions and countries.

This shows different possible species responses to different degrees of agriculture intensification and production. On the other hand, biodiversity also affects production via ecosystems services. Crops depend on pollination by bees and other arthropods [75], predation that decrease the levels of pest by birds [76], bats [77] and insects [78] are examples of such. Pollination estimated in 153 billion euros worldwide [79] and long term agriculture intensification can extirpate $50 \%$ of the bee species causing great economic loses [80]. Additionally,

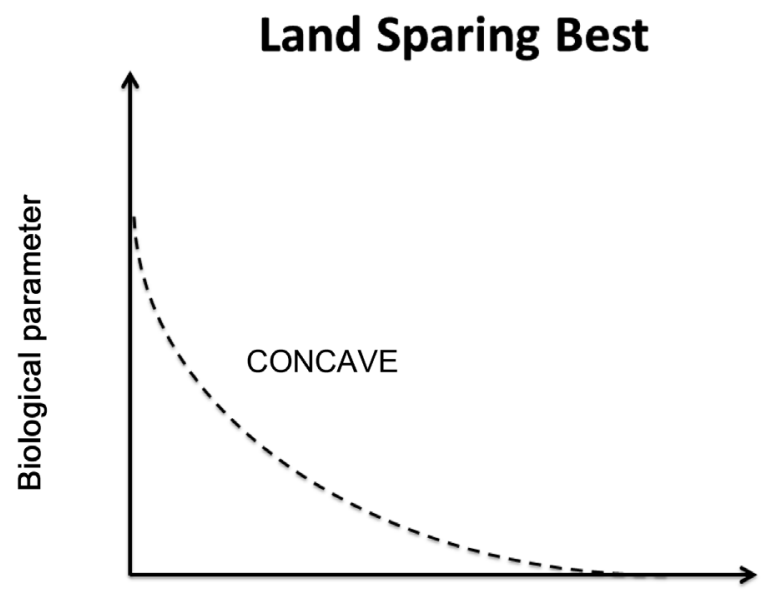

Production parameter

(a)

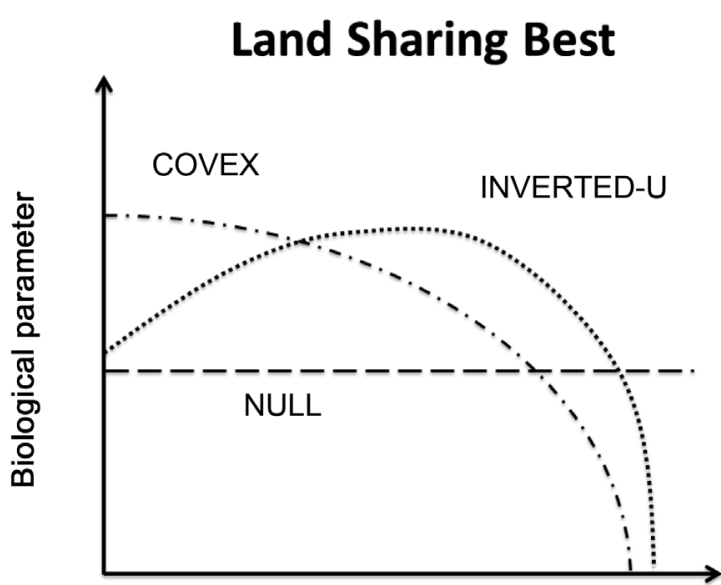

Production parameter

(b)

Figure 1. Concave relationship between biological parameters and production used to stress LSP efficiency (left hand side). Convex, inverted-U and null patterns, which are assumed to support LSH performance. 
Table 2. Different biological responses to agriculture intensification and production.

\begin{tabular}{|c|c|c|c|c|}
\hline Curve type & $\begin{array}{l}\text { Species group and biological } \\
\text { parameter }^{1}\end{array}$ & Systems & Region & Reference \\
\hline \multirow[t]{4}{*}{$\begin{array}{l}\text { Inverted-u } \\
\text { LSH best }\end{array}$} & $\begin{array}{l}\text { Occurrence of grasslands } \\
\text { endangered birds }\end{array}$ & Pastoral arable systems & $\begin{array}{l}\text { Different parts of the } \\
\text { world (Asia, North } \\
\text { America, South America) }\end{array}$ & [89] \\
\hline & $\begin{array}{l}\text { Annual plant richness } \\
\text { (including exotics) }\end{array}$ & Sheep cattle grazing & $\begin{array}{l}\text { Woodlands in eastern } \\
\text { Australia }\end{array}$ & [90] \\
\hline & $\begin{array}{l}\text { Abundance of Amazona } \\
\text { aestiva (blue fronted Amazon) }\end{array}$ & $\begin{array}{l}\text { Agroforestry homegardens } \\
\text { and pasture }\end{array}$ & Brazil & [7] \\
\hline & Bumble and solitary bees & $\begin{array}{l}\text { Organic and conventional } \\
\text { cereal farms }\end{array}$ & England & [9] \\
\hline \multirow{5}{*}{$\begin{array}{l}\text { Negative } \\
\text { concave } \\
\text { LSP best }\end{array}$} & Butterflies richness & Coffee systems & Mexico & [47] \\
\hline & Richness of birds & $\begin{array}{l}\text { Mixed farms (including } \\
\text { coffee, rice, maize, beans } \\
\text { cassava and so on) }\end{array}$ & Uganda & [10] \\
\hline & Birds and plant richness & Agroforestry/monoculture crops & & [91] \\
\hline & $\begin{array}{l}\text { Abundance of Cyanocorax } \\
\text { chrysops (Plush-crested Jay) }\end{array}$ & $\begin{array}{l}\text { Agroforestry homegardens } \\
\text { and pasture }\end{array}$ & Brazil & {$[7]$} \\
\hline & Butterfly richness & $\begin{array}{l}\text { Organic and conventional } \\
\text { cereal farms }\end{array}$ & England & [9] \\
\hline \multirow{4}{*}{$\begin{array}{l}\text { Negative } \\
\text { convex } \\
\text { LSH best }\end{array}$} & Butterfly richness & Agroforestry/monoculture crops & & [91] \\
\hline & Ant richness & $\begin{array}{l}\text { Coffee systems with different } \\
\text { intensification levels }\end{array}$ & Mexico & [47] \\
\hline & Dung beetles richness & Agroforestry/monoculture crops & Indonesia & [91] \\
\hline & Mammals and dung beetles & Banana and cacao agroforestry & & [92] \\
\hline \multirow[t]{3}{*}{$\begin{array}{c}\text { Null } \\
\text { LSH best }\end{array}$} & $\begin{array}{l}\text { Epiphytic understory } \\
\text { bryophytes, leaf litter ants } \\
\text { and bees richness }\end{array}$ & $\begin{array}{c}\text { Cacao agroforestry and open sun } \\
\text { plantations }\end{array}$ & Indonesia & [93] \\
\hline & $\begin{array}{l}\text { Richness of trees, endophytic } \\
\text { fungus, spiders, ants, } \\
\text { herpetofauna, rats, } \\
\text { birds and butterflies }\end{array}$ & $\begin{array}{l}\text { Small landholder cocoa } \\
\text { agroforestry and } \\
\text { intensive systems }\end{array}$ & Indonesia & [90] \\
\hline & Plant richness & Organic and conventional farms & England & [9] \\
\hline
\end{tabular}

landscape context exert significant effect on species in the agricultural lands and richness and abundance is largely affected by the presence of nearby forest [81]. Therefore, ecosystems provision, such as pollination and pest predation pressure largely depends on landscape context, and nearby natural habitat margins, which positively affects natural capital [81]. All of this is not considered in by the LSP hypothesis as it assumes that the biological parameter is not causally related to production [11] [12].

\section{Land-Use and Ecological Responses in Dynamic Landscapes}

In the land use and economic session, we showed that yield increase seldom leads to a stasis or farmed area contraction (Session 2.1). The economic aspects that lead to this rebound effect in yield farm-expansion relationship (Jevons Paradox) were also presented (Session 2.3). Further, the responses of species and ecosystems services to increasing intensification levels were discussed (Session 2.5). We here present a conceptual model to understand 
the ecological and ecosystems consequences of different land-use dynamics associated to agriculture intensification.

Upper diagram in Figure 2 shows nine landscapes (A to E”) composed of different proportions of natural habitat $(\mathrm{NH})$ and farming area, as well as different degrees of agriculture intensification on the agriculture part (AI). Landscapes can change in all directions according to changes in natural habitat proportions and agriculture intensification levels (side arrows). Agroecological conversion changes landscapes in the downward direction (for example from C to C', D to D', E' to E', and so on), while agriculture intensification is the upward opposite trend (B" to B', D' to D and E' to E and son on). From left to right, decrease in NH characterizes "natural habitat" contraction, and the right to left change is the "natural habitat" expansion or Forest Transition. A is a landscape totally occupied by "natural habitat", B consist of $80 \%$ of habitat cover proportion and agriculture intensification index of farming area is 0.2 , B' has 0.8 of habitat cover and agriculture intensification index is 0.5 and so on. Here we use the term "natural habitat" in the operational sense, defining it as areas subjected to very low levels of human intervention, rather than in the philosophical sense which refers to it as untouched or untamed nature [73]. Additionally, the available data of remote sensing about wood cover, as well as theoretical approaches to estimate populations sizes, uses this term, which will simplify our analyses, enabling to address regional issues, as will be further developed.

Farming systems in which AI is equals to 1 are characterized by high input, low heterogeneity and high levels of human disturbance and low planned and associated diversity. Traditional and polyculture (sensu Moguel

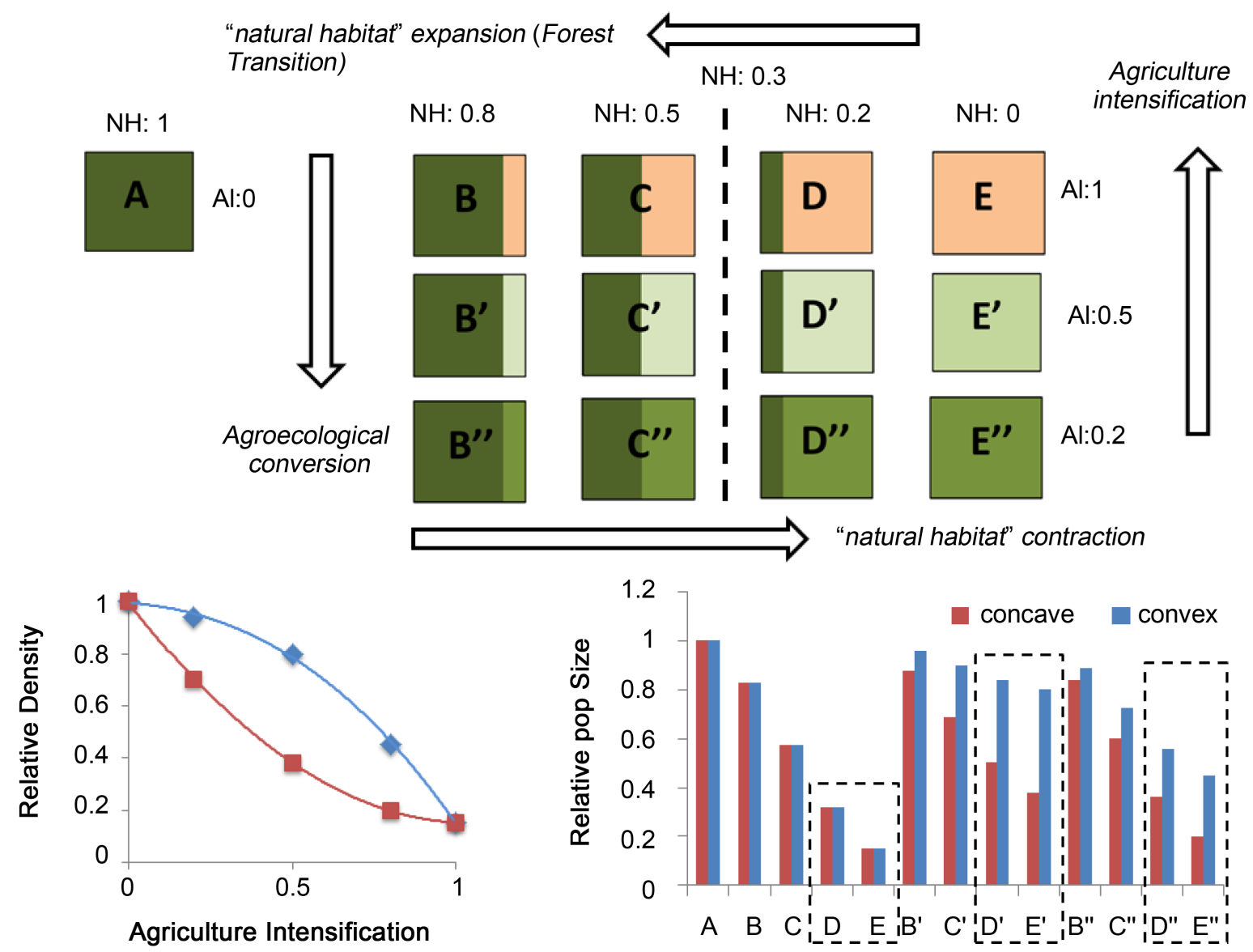

Figure 2. Relationships among landscape population size (bottom right) of different landscapes composed by different habitat and agriculture proportions, subjected to different agriculture intensification degrees (top figure), given the species concave and convex responses to intensification assuming the same functions as Green et al. (2005) (bottom left). Dashed line in the upper figure represents the $30 \%$ threshold of habitat cover, bellow which population size in the natural habitat is predicted to decrease disproportionally (such as in landscapes D, D', D”, E, E' and E”), and dashed boxes in bottom right figure show landscapes bellow this threshold. 
Toledo, [82]), home gardens [7] and low shade agroforestry are considered having agriculture intensification equals to 0.5 . Finally, we assume that agroforestry and extractives systems locate at 0.2 on the intensification scale.

Using the equations of main concave and convex responses of species groups presented by Greens and colleagues (2005) [2] in bottom left and total population sizes in the nine landscapes are presented (considering both farmed and unfarmed portion), followed by the simple linear "equation:"

$$
\begin{gathered}
\text { Total Relative Pop Size }=\text { "Natural habitat" Pop size }+ \text { Farm area Pop Size } \\
\text { "Natural habitat" Pop size }=\mathrm{D}_{\mathrm{NH}} \times \mathrm{A}_{\mathrm{NH}} \\
\text { Farm area Pop Size }=\mathrm{D}_{\mathrm{FA}} \times \mathrm{A}_{\mathrm{FA}}
\end{gathered}
$$

where:

$\mathrm{D}_{\mathrm{NH}}$ is the relative density on the "natural area".

$\mathrm{A}_{\mathrm{NH}}$ is "natural habitat" area.

$\mathrm{D}_{\mathrm{FA}}$ is density on farmed area.

$\mathrm{A}_{\mathrm{FA}}$ is farmed area.

On the other hand, theoretical and empirical studies show that fragmentation affects population inhabiting these patchy landscapes in a non-linear association. Particularly, population sizes falls steeply below $30 \%$ of habitat cover proportion [83], which represented by the dashed line in the upper diagram of Figure 2. Although we assumed a linear area-density relationship in the bottom right graphic, total population size in landscapes with less than $30 \%$ of habitat proportion (dashed boxes on the bottom right graphic) is overestimated for not accounting for decrease in habitat population pool. Because species response to fragmentations depend on several factors such as timing since fragmentation, species specific time-lags in the response to habitat contraction [84], and differential functional response given to sensitive to human disturbs (e.g. concave species may suffer more from habitat loss due to being more sensitive), making precise estimations rather uncertain. To make our model simple and reliable, we did not incorporate this non-linear aspects assuming that density is fixed regardless of habitat area. Therefore, values in dashed boxes may be overestimated, which is of further conservation concern as will be further discussed.

According to LSP proponents, moving upward in the diagram (increasing AI) will reflect in changes in the left direction, inducing habitat expansion (such as paths $D^{\prime} \rightarrow D \rightarrow C$ and $E^{\prime \prime} \rightarrow E^{\prime} \rightarrow D^{\prime}$ ). Jevons Paradox, on the other hand, concern increasing yields inducing habitat reduction (favoring paths such as $\mathrm{D}^{\prime} \rightarrow \mathrm{D} \rightarrow \mathrm{E}$ and $\mathrm{C}^{\prime} \rightarrow \mathrm{C} \rightarrow \mathrm{D}$ ). As we show in the land-use and economic session, although forest transition fostered by yield increase occurs by some extent, the Jevons Paradox is much more frequent [16]. As intensification increases farm area and decrease biodiversity in agriculture portion, as well as in the habitat portion (via increasing habitat loss), landscapes will change in D or E direction, tending to very low associated landscape biodiversity. Due to the fact that actual population sizes must be smaller than presented lower right graphic in Figure 2 as above mentioned, these landscapes with small habitat proportion, which are patchily distributed and embedded in intensive matrixes, may harbor very few species, specially sometime after fragmentation and intensification. Decrease on population sizes of once common species in the European farmlands show the extreme effects of agriculture intensification at long term [85]. Unfortunately, tropical landscapes undergoing to agriculture intensification may face similar problems in the future.

Most of the tropical high biodiverse regions (named biodiversity hotspots), such as the Brazilian Cerrado, Atlantic Forest, Meso-America, Western-Ghats and and Siri Lanka [86] are around or below the 30\% habitat cover and simultaneously undergoing agriculture intensification. This multiple effects reduce populations sizes in the matrix, as well as biological fluxes among habitat patches [4]. This combination of increasing deforestation and matrix agriculture intensification is predicted to cause local and global extinctions at long term. On the other hand, if intermediate levels of agriculture are maintained (B', C', D' and E') as assumed by LSH hypothesis, and habitat loss is controlled, significant amount of biodiversity is maintained although at lower levels then the "original" non-managed landscape (A). Hence, low to intermediate levels of intensification may induce less habitat loss maintaining biodiversity at both farmlands and natural remnants, as well as maintain matrix permeability functionally connecting population inhabiting the habitat patches [87].

Furthermore, to give a general idea of how these land-use dynamics may affect ecosystems services provision on the agricultural lands Figure 3 is the schematic representation of landscapes C, D, C' and D'. "Natural habitat" support adjacent agricultural areas with ecosystems services (such as pest predation and pollination). 

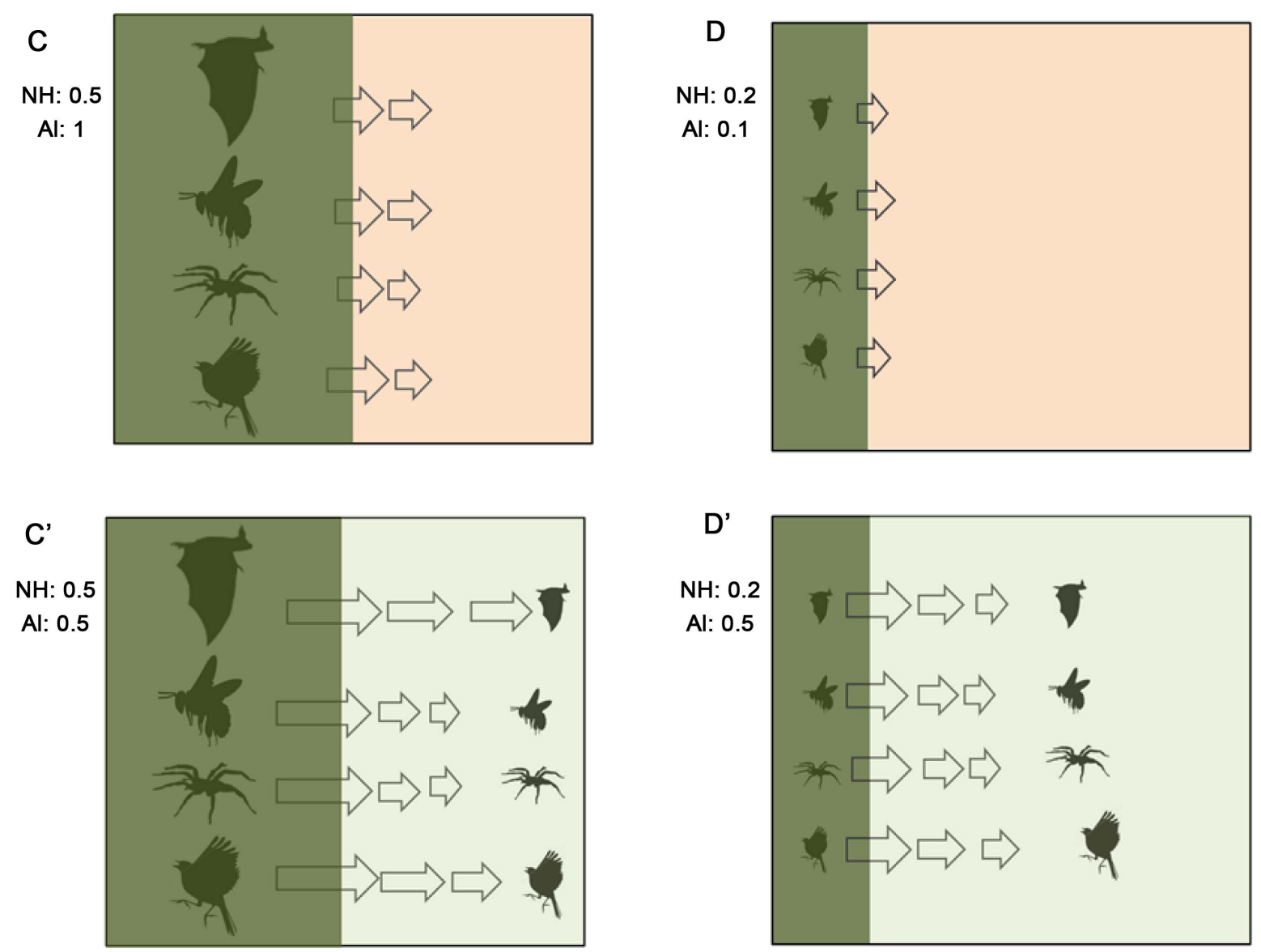

Figure 3. Conceptual representation of the ecosystems services patterns on landscapes C, D, C' and D' (see Figure 3) with different $\mathrm{AI}$ and $\mathrm{NH}$. Animal figures represent breeding population of ecosystems services providing species and figure size is related to population relative numbers. Predators are represented by spiders, insectivore birds and bats, while pollinators are represented by bees. Arrows represent ecosystems services performed by populations that reproduce in the "natural habitat" portion, and provide natural capital to adjacent agriculture areas through habitat supplementation and dispersal. Arrow size represent the intensity and the extent of this provision.

Population numbers of ecosystems providing species is represented as animal figure sizes. Arrow represents habitat supplementation (utilization of the adjacent matrix outside "habitat patch" by individuals that inhabit the patch, sensu [88]) and arrow size represent the intensity of this provision. Also, at intermediate levels of agriculture intensification, the matrix may act as a population source by serving as a feeding and reproductive site [87]. Because permeability of intensive farming is low in C and D landscapes, natural capital may be only provided nearby the natural habitat border (smaller and fewer arrows). Further, most species may not reproduce in the intensive matrixes although they might reproduce in non-intensive ones [88]. Finally, D landscapes may suffer from loss of ecosystem services due to the reduction of the populations inhabiting small habitat fragments (less than $30 \%$ of habitat cover) coped with intensification of farmlands.

On the other hand, intermediate levels of agriculture intensification in the matrix and yet maintaining significant amount of natural habitat (preferably more than 30\%) may provide agricultural fields with ecosystems services. Because species importance is associated with their abundance, many groups that promote these ecosystems services my follow convex patterns in density and intensification relationship and thus may maintain large populations in intermediate levels of agriculture intensification .

\section{Final Remarks}

This review shows that the main premise of LSP_namely that increasing yield will reduce further habitat loss-is not supported either by theoretical or empirical data. Furthermore, a LSP business-as-usual strategy is 
Table 3. Issues need addressing in the LSP-LSH debate given different disciplines.

\begin{tabular}{|c|c|}
\hline & Issues need addressing \\
\hline Land-use & $\begin{array}{l}\text { + How biophysical, ecological, economic and cultural factors affect the Jevons Paradox or the Forest } \\
\text { transition trends? } \\
\text { +Effect of non-intensive agriculture on habitat loss }\end{array}$ \\
\hline Economic & $\begin{array}{l}\text { +Understand the macroeconomic aspects of intensification (such as effect of trade, export policies and } \\
\text { certification) }\end{array}$ \\
\hline $\begin{array}{l}\text { Agriculture production and } \\
\text { food security }\end{array}$ & $\begin{array}{l}\text { +Develop agroecological methods of increasing yield and analyze its efficiency } \\
\text { +Better understand the role of the whole food chain (production, retailers and consumers) on either } \\
\text { enhancing or hampering governance arrangements for securing food }\end{array}$ \\
\hline $\begin{array}{l}\text { Ecology and ecosystem } \\
\text { services }\end{array}$ & $\begin{array}{l}\text { +Meta-analyses of the current knowledge of agriculture intensification on different species in tropical } \\
\text { and temperate regions } \\
\text { +Quantify ecosystems loss due to intensification in different spatial and temporal scales } \\
\text { +Use other biological indicator other than species richness, such as composition, endemic rate and } \\
\text { phylogenetic diversity }\end{array}$ \\
\hline
\end{tabular}

predicted to increase habitat loss. Although it is clear that potential and realized yield gap should be narrowed, many countries have decreased hunger by investing on food access, sanitation education, health and so on through local and country scale food policies. Many of the studies have compared biodiversity and agricultural production under "intensive vs. non-intensive" management and "natural habitats". These studies assume that, depending on the species richness/abundance and yield shape, either LSP or LSH strategies will be more effective. Beyond the well-known concave and convex patterns, also U-shaped and null models are also possible. Furthermore, species responses alone are not sufficient to compare LSP and LSH efficiency, as the relationship between agriculture output, farm expansion/retraction and habitat loss is of ultimate importance. As intensification generally leads to increase habitat loss, even if species respond on a convex fashion, habitat loss and intensification may lead to population declines at both farmed and unfarmed portions, suggesting the low or even negative biological consequences of LSP management.

Our theoretical model shows that the risks of Jevons Paradox in the yield-forest loss relationship to biodiversity and ecosystems services provision are multiple. Increasing intensification of farmlands: 1) increases natural habitat loss declining population inhabiting these small habitat patches especially in regions with less than $30 \%$ of habitat cover; 2) leads to population declines for species inhabiting the anthropogenic matrix (due to loss of heterogeneity, pesticide use and so on); 3) decreases permeability of the natural habitat dwelling species that are either crossing the matrix in dispersal movements or as a daily home range movement supplementing habitat. The situation is even worrisome in landscapes where "natural habitat" cover is lower than 30\%, such as many biodiversity host spots (such as the Brazilian Atlantic Forest and the Cerrado). In such places, conservation strategies that support agricultural intensification may be a shoot on biodiversity's feet and yet may not guarantee food security.

Both sparing and sharing assumes complex causal chains that involve biophysical, ecological and cultural world that transcends several scientific disciplines and many issues are still to be addressed (Table 3). Yet, LSP practices may deeply impact biodiversity, ecosystems services, food security and social wellbeing leading to a no-win scenario, although, local and small scale LSP may work in specific situations [57]. Therefore, by and large, LSH is a safer strategy from ecological and social aspects. This review shows that responses are very context-specific given the biological, land-use and societal issues.

\section{Acknowledgements}

We are thankful to Professor Tim O’Riordan for discussing, commenting and editing the text. We are also grateful to two anonymous reviewers for its suggestions to improve a previous version of the manuscript. Funding was provided by CAPES and CNPq. We thank the Mestrado em Análise e Modelagem de Sistemas Ambientais for a post-doctorate fellowship to FFG. SCR recieved a post-doctorate fellowship CNPQ BJT 300013/2015-9.

\section{References}

[1] Phalan, B., Green, R.E., Dicks, L.V., Dotta, G., Feniuk, C., Lamb, A., Balmford, A., et al. (2016) How Can Higher- 
Yield Farming Help to Spare Nature? Science, 351, 450-451. http://dx.doi.org/10.1126/science.aad0055

[2] Green, R.E., Cornell, S.J., Scharlemann, J.P. and Balmford, A. (2005) Farming and the Fate of Wild Nature. Science, 307, 550-555. http://dx.doi.org/10.1126/science.1106049

[3] Phalan, B., Onial, M., Balmford, A. and Green, R.E. (2011) Reconciling Food Production and Biodiversity Conservation: Land Sharing and Land Sparing Compared. Science, 333, 1289-1291. http://dx.doi.org/10.1126/science.1208742

[4] Perfecto, I. and Vandermeer, J. (2010) The Agroecological Matrix as Alternative to the Land-Sparing/Agriculture Intensification Model. Proceedings of the National Academy of Sciences of the United States of America, 107, 57865791. http://dx.doi.org/10.1073/pnas.0905455107

[5] Clough, Y., Barkmann, J., Juhrbandt, J., Kessler, M., Wanger, T.C., Anshary, A., et al. (2011) Combining High Biodiversity with High Yields in Tropical Agroforests. Proceedings of the National Academy of Sciences of the United States of America, 108, 8311-8316. http://dx.doi.org/10.1073/pnas.1016799108

[6] Komar, O. (2006) Priority Contribution. Ecology and Conservation of Birds in Coffee Plantations: A Critical Review. Bird Conservation International, 16, 1-23. http://dx.doi.org/10.1017/S0959270906000074

[7] Goulart, F.F., Vandermeer, J., Perfecto, I. and da Matta-Machado, R.P. (2011) Frugivory by Five Bird Species in Agroforest Home Gardens of Pontal do Paranapanema, Brazil. Agroforestry Systems, 82, 239-246. http://dx.doi.org/10.1007/s10457-011-9398-z

[8] Bengtsson, J., Ahnström, J. and Weibull, A.C. (2005) The Effects of Organic Agriculture on Biodiversity and Abundance: A Meta-Analysis. Journal of Applied Ecology, 42, 261-269. http://dx.doi.org/10.1111/j.1365-2664.2005.01005.x

[9] Gabriel, D., Sait, S.M., Kunin, W.E. and Benton, T.G. (2013) Food Production vs. Biodiversity: Comparing Organic and Conventional Agriculture. Journal of Applied Ecology, 50, 355-364. http://dx.doi.org/10.1111/1365-2664.12035

[10] Hulme, M.F., Vickery, J.A., Green, R.E., Phalan, B., Chamberlain, D.E., Pomeroy, D.E., et al. (2013) Conserving the Birds of Uganda's Banana-Coffee Arc: Land Sparing and Land Sharing Compared. PLoS ONE, 8, e54597. http://dx.doi.org/10.1371/journal.pone.0054597

[11] Matson, P.A. and Vitousek, P.M. (2006) Agricultural Intensification: Will Land Spared from Farming Be Land Spared for Nature? Conservation Biology, 20, 709-710. http://dx.doi.org/10.1111/j.1523-1739.2006.00442.X

[12] Goulart, F.F., Jacobson, T.K.B., Zimbres, B.Q.C., Machado, R.B., Aguiar, L.M.S. and Fernandes, G.W. (2012) Agricultural Systems and the Conservation of Biodiversity and Ecosystems in the Tropics. InTech Press, Rijeka.

[13] Fianko, J.R., Donkor, A., Lowor, S.T., Yeboah, P.O., Glover, E.T., Adom, T. and Faanu, A. (2011) Health Risk Associated with Pesticide Contamination of Fish from the Densu River Basin in Ghana. Journal of Environmental Protection, 2, 115. http://dx.doi.org/10.4236/jep.2011.22013

[14] Pandey, P., Khillare, P.S. and Kumar, K. (2011) Assessment of Organochlorine Pesticide Residues in the Surface Sediments of River Yamuna in Delhi, India. Journal of Environmental Protection, 2, 511. http://dx.doi.org/10.4236/jep.2011.25059

[15] Kromann, P., Pradel, W., Cole, D., Taipe, A. and Forbes, G.A. (2011) Use of the Environmental Impact Quotient to Estimate Health and Environmental Impacts of Pesticide Usage in Peruvian and Ecuadorian Potato Production. Journal of Environmental Protection, 2, 581. http://dx.doi.org/10.4236/jep.2011.25067

[16] Rudel, T.K., Schneider, L., Uriarte, M., Turner, B.L., DeFries, R., Lawrence, D., et al. (2009) Agricultural Intensification and Changes in Cultivated Areas, 1970-2005. Proceedings of the National Academy of Sciences of the United States of America, 106, 20675-20680. http://dx.doi.org/10.1073/pnas.0812540106

[17] Ceddia, M.G., Bardsley, N.O., Gomez-y-Paloma, S. and Sedlacek, S. (2014) Governance, Agricultural Intensification, and Land Sparing in Tropical South America. Proceedings of the National Academy of Sciences of the United States of America, 111, 7242-7247. http://dx.doi.org/10.1073/pnas.1317967111

[18] Vandermeer, J., Perfecto, I., Green, R.E., Cornell, S.J., Scharlemann, J.P.W. and Balmford, A. (2005) The Future of Farming and Conservation. Science, 308, 1257-1258. http://dx.doi.org/10.1126/science.308.5726.1257b

[19] Rusch, A., Chaplin-Kramer, R., Gardiner, M.M., Hawro, V., Holland, J., Landis, D., et al. (2016) Agricultural Landscape Simplification Reduces Natural Pest Control: A Quantitative Synthesis. Agriculture, Ecosystems \& Environment, 221, 198-204. http://dx.doi.org/10.1016/j.agee.2016.01.039

[20] Oke, D. and Olatiilu, A. (2011) Carbon Storage in Agroecosystems: A Case Study of the Cocoa Based Agroforestry in Ogbese Forest Reserve, Ekiti State, Nigeria. Journal of Environmental Protection, 2, 1069-1075. http://dx.doi.org/10.4236/jep.2011.28123

[21] Tscharntke, T., Clough, Y., Wanger, T.C., Jackson, L., Motzke, I., Perfecto, I., et al. (2012) Global Food Security, Biodiversity Conservation and the Future of Agricultural Intensification. Biological Conservation, 151, 53-59.

http://dx.doi.org/10.1016/j.biocon.2012.01.068 
[22] Kremen, C. (2015) Reframing the Land-Sparing/Land-Sharing Debate for Biodiversity Conservation. Annals of the New York Academy of Sciences, 1355, 52-76. http://dx.doi.org/10.1111/nyas.12845

[23] Chappell, M.J. and LaValle, L.A. (2011) Food Security and Biodiversity: Can We Have Both? An Agroecological Analysis. Agriculture and Human Values, 28, 3-26. http://dx.doi.org/10.1007/s10460-009-9251-4

[24] Fischer, J., Brosi, B., Daily, G.C., Ehrlich, P.R., Goldman, R., Goldstein, J., et al. (2008) Should Agricultural Policies Encourage Land Sparing or Wildlife-Friendly Farming? Frontiers in Ecology and the Environment, 6, 380-385. http://dx.doi.org/10.1890/070019

[25] Mather, A.S. (1992) The Forest Transition. Area, 24, 367-379.

[26] Angelsen, A. and Kaimowitz, D. (2001) Agricultural Technologies and Tropical Deforestation. CAB, Wallingford. http://dx.doi.org/10.1079/9780851994512.0000

[27] Mather, A.S. (2007) Recent Asian Forest Transitions in Relation to Forest-Transition Theory. International Forestry Review, 9, 491-502.

[28] Carvalho Ribeiro, S.M. and Lovett, A. (2009) Associations between Forest Characteristics and Socio-Economic Development: A Case Study from Portugal. Journal of Environmental Management, 90, 2873-2881. http://dx.doi.org/10.1016/j.jenvman.2008.02.014

[29] Trading Economics Data (2016). http://www.tradingeconomics.com/brazil/exports

[30] Aukland, L., Costa, P.M. and Brown, S. (2003) A Conceptual Framework and Its Application for Addressing Leakage: The Case of Avoided Deforestation. Climate Policy, 3, 123-136. http://dx.doi.org/10.3763/cpol.2003.0316

[31] Gibbs, H.K., Rausch, L., Munger, J., Schelly, I., Morton, D.C., Noojipady, P., et al. (2015) Brazil’s Soy Moratorium. Science, 347, 377-378. http://dx.doi.org/10.1126/science.aaa0181

[32] Kauffman, D., Kraay, A. and Mastruzzi, M. (2009) Governance Matters VIII: Aggregate and Individual Governance Indicators. World Bank Policy Research Working Paper 4978, World Bank, Washington DC.

[33] Schroth, G., Ed. (2004) Agroforestry and Biodiversity Conservation in Tropical Landscapes. Island Press, Washington DC.

[34] Goulart, F.G., Nelson, E., Galán, A.L. and Soares-Filho, B. Conservation and Sustainable Lessons from Cuba. Accepted for publication in Conservation Biology, in press.

[35] Boucher, D.H. (2012) Land Sparing: It’s an Economic Question. The Preliminary Program for 97th ESA Annual Meeting, 5-10August 2012.

[36] Kuwornu, J.K.M., Agyei-Holmes, A. and Osei-Asare, Y.B. (2011) Econometric Analysis of Cocoa Production and Deforestation in Ghana: The Role of Technological Innovations. World Journal of Agricultural Sciences, 7, 722-732.

[37] Grau, H.R., Gasparri, N.I. and Aide, T.M. (2008) Balancing Food Production and Nature Conservation in the Neotropical Dry Forests of Northern Argentina. Global Change Biology, 14, 985-997. http://dx.doi.org/10.1111/j.1365-2486.2008.01554.x

[38] García-Barrios, L., Galván-Miyoshi, Y.M., Valsieso-Pérez, I.A., Masera, O.R., Bocco, G. and Vandermeer, J. (2009) Neotropical Forest Conservation, Agricultural Intensification, and Rural Out-Migration: The Mexican Experience. BioScience, 59, 863-873. http://dx.doi.org/10.1525/bio.2009.59.10.8

[39] Ewers, R.M., Scharlemann, J.P., Balmford, A. and Green, R.E. (2009) Do Increases in Agricultural Yield Spare Land for Nature? Global Change Biology, 15, 1716-1726. http://dx.doi.org/10.1111/j.1365-2486.2009.01849.x

[40] Soares Filho, B., Lima, L., Bowman, M. and Viana, L. (2012) Challenges for Low-Carbon Agriculture and Forest Conservation in Brazil. Inter-American Development Bank.

[41] Richards, P.D. (2012) Food, Fuel, and the Hidden Margins of Capital. Journal of Land Use Science, 7, 289-310. http://dx.doi.org/10.1080/1747423X.2011.565373

[42] Burbach, R. and Flynn, P. (1980) Agribusiness in the Americas. Monthly Review Press and North American Congress on Latin America, New York.

[43] McIntyre, B.D, Herren, H.R., Wakhungu, J. and Watson, R.T. (2009) Agriculture at a Crossroads. International Assessment of Agricultural Knowledge, Science and Technology for Development (IAASTD): Global Report. Synthesis Report, Island Press, Washington DC, 590.

[44] Mills, J.H. and Waite, T.A. (2009) Economic Prosperity, Biodiversity Conservation, and the Environmental Kuznets Curve. Ecological Economics, 68, 2087-2095. http://dx.doi.org/10.1016/j.ecolecon.2009.01.017

[45] Jevons, W.S. (1865) The Coal Question: An Inquiry Concerning the Progress of the Nation, and the Probable Exhaustion of Our Coal Mines. Augustus M. Kelley, New York.

[46] Brazilian Ministry of Agriculture (2016). http://www.agricultura.gov.br 
[47] Perfecto, I., Mas, A., Dietsch, T. and Vandermeer, J. (2003) Conservation of Biodiversity in Coffee Agroecosystems: A Tri-Taxa Comparison in Southern Mexico. Biodiversity \& Conservation, 12, 1239-1252.

[48] Reganold, J.P., Glover, J.D., Andrews, P.K. and Hinman, H.R. (2001) Sustainability of Three Apple Production Systems. Nature, 410, 926-930. http://dx.doi.org/10.1038/35073574

[49] Grau, R., Kuemmerle, T. and Macchi, L. (2013) Beyond “Land Sparing versus Land Sharing”: Environmental Heterogeneity, Globalization and the Balance between Agricultural Production and Nature Conservation. Current Opinion in Environmental Sustainability, 5, 477-483. http://dx.doi.org/10.1016/j.cosust.2013.06.001

[50] Pinstrup-Andersen, P. (2009) Food Security: Definition and Measurement. Food Security, 1, 5-7. http://dx.doi.org/10.1007/s12571-008-0002-y

[51] Goulart, F.F., Vandermeer, J., Perfecto, I. and Matta-Machado, R.P. (2009) Análise agroecológica de dois paradigmas modernos. Revista Brasileira de Agroecologia, 4, 76-85.

[52] Stanhill, G. (1990) The Comparative Productivity of Organic Agriculture. Agriculture, Ecosystems \& Environment, 30, 1-26. http://dx.doi.org/10.1016/0167-8809(90)90179-H

[53] Badgley, C. and Perfecto, I. (2007) Can Organic Agriculture Feed the World? Renewable Agriculture and Food Systems, 22, 80-86. http://dx.doi.org/10.1017/S1742170507001986

[54] Seufert, V., Ramankutty, N. and Foley, J.A. (2012) The Yield Performance of Organic Agriculture. Proceedings of the 8th International Conference on Life Cycle Assessment in the Agri-Food Sector (LCA Food 2012), 1-4.

[55] FAO (2014) The State of Food and Agriculture: Innovation in Family Farming. http://www.fao.org/publications/sofa/en/

[56] Rosset, P. (1999) The Multiple Functions and Benefits of Small Farm Agriculture. Policy Brief, 4.

[57] Chandler, R.B., King, D.I., Raudales, R., Trubey, R., Chandler, C. and Arce Chávez, V.J. (2013) A Small-Scale LandSparing Approach to Conserving Biological Diversity in Tropical Agricultural Landscapes. Conservation Biology, 27, 785-795. http://dx.doi.org/10.1111/cobi.12046

[58] Gomiero, T., Pimentel, D. and Paoletti, M.G. (2011) Environmental Impact of Different Agricultural Management Practices: Conventional vs. Organic Agriculture. Critical Reviews in Plant Sciences, 30, 95-124. http://dx.doi.org/10.1080/07352689.2011.554355

[59] Ajanovic, A. (2011) Biofuels versus Food Production: Does Biofuels Production Increase Food Prices? Energy, 36, 2070-2076. http://dx.doi.org/10.1016/j.energy.2010.05.019

[60] Foley, J.A., Ramankutty, N., Brauman, K.A., Cassidy, E.S., Gerber, J.S., Johnston, M., et al. (2011) Solutions for a Cultivated Planet. Nature, 478, 337-342. http://dx.doi.org/10.1038/nature10452

[61] Gustavsson, J., Cederberg, C., Sonesson, U., Van Otterdijk, R. and Meybeck, A. (2011) Global Food Losses and Food Waste: extent, Causes and Prevention. FAO, Rome.

[62] Pimentel, D. and Pimentel, M. (2003) Sustainability of Meat-Based and Plant-Based Diets and the Environment. The American Journal of Clinical Nutrition, 78, 660S-663S.

[63] Lobell, D.B., Cassman, K.G. and Field, C.B. (2009) Crop Yield Gaps: Their Importance, Magnitudes, and Causes. Annual Review of Environment and Resources, 34, 179-204. http://dx.doi.org/10.1146/annurev.environ.041008.093740

[64] Cunningham, S.A., Attwood, S.J., Bawa, K.S., Benton, T.G., Broadhurst, L.M., Didham, R.K., et al. (2013) To Close the Yield-Gap While Saving Biodiversity Will Require Multiple Locally Relevant Strategies. Agriculture, Ecosystems \& Environment, 173, 20-27. http://dx.doi.org/10.1016/j.agee.2013.04.007

[65] Bommarco, R., Kleijn, D. and Potts, S.G. (2013) Ecological Intensification: Harnessing Ecosystem Services for Food Security. Trends in Ecology \& Evolution, 28, 230-238.

[66] Hobbs, P.R., Sayre, K. and Gupta, R. (2008) The Role of Conservation Agriculture in Sustainable Agriculture. Philosophical Transactions of the Royal Society B, 363, 543-555. http://dx.doi.org/10.1098/rstb.2007.2169

[67] Cassman, K.G. (1999) Ecological Intensification of Cereal Production Systems: Yield Potential, Soil Quality, and Precision Agriculture. Proceedings of the National Academy of Sciences of the United States of America, 96, 5952-5959. http://dx.doi.org/10.1073/pnas.96.11.5952

[68] Pretty, J.N., Noble, A.D., Bossio, D., Dixon, J., Hine, R.E., Penning de Vries, F.W. and Morison, J.I. (2006) ResourceConserving Agriculture Increases Yields in Developing Countries. Environmental Science \& Technology, 40, 11141119. http://dx.doi.org/10.1021/es051670d

[69] Lam, T. and Ingram, J. (2013) Food Security Twists and Turns-Why Food Systems Need Complex Governance? In: O’Riordan, T. and Lenton, T., Eds., Addressing Tipping Points for a Precarious Future, British Academy Scholarship, Oxford, 81-103.

[70] MacArthur, R. and Wilson, E. (1967) The Theory of Biogeography. Princeton University Press, Princeton, 19-67. 
[71] Fischer, J. and Lindenmayer, D. (2006) Beyond Fragmentation: The Continuum Model for Fauna Research and Conservation in Human-Modified Landscapes. Oikos, 112, 473-480. http://dx.doi.org/10.1111/j.0030-1299.2006.14148.x

[72] Hanski, I. and Hanski, I.A. (1999) Metapopulation Ecology. Vol. 232, Oxford University Press, Oxford.

[73] Goulart, F.F., Salles, P., Saito, C.H. and Machado, R.B. (2013) How Do Different Agricultural Management Strategies Affect Bird Communities Inhabiting a Savanna-Forest Mosaic? A Qualitative Reasoning Approach. Agriculture, Ecosystems \& Environment, 164, 114-130. http://dx.doi.org/10.1016/j.agee.2012.09.011

[74] Connell, J.H. (1978) Diversity in Tropical Rain Forests and Coral Reefs. Science, 199, 1302-1310. http://dx.doi.org/10.1126/science.199.4335.1302

[75] Klein, A.M., Vaissiere, B.E., Cane, J.H., Steffan-Dewenter, I., Cunningham, S.A., Kremen, C. and Tscharntke, T. (2007) Importance of Pollinators in Changing Landscapes for World Crops. Proceedings of the Royal Society B, 274, 303-313. http://dx.doi.org/10.1098/rspb.2006.3721

[76] Perfecto, I., Vandermeer, J.H., Bautista, G.L., Nunez, G.I., Greenberg, R., Bichier, P. and Langridge, S. (2004) Greater Predation in Shaded Coffee Farms: The Role of Resident Neotropical Birds. Ecology, 85, 2677-2681. http://dx.doi.org/10.1890/03-3145

[77] Zhang, W., Ricketts, T.H., Kremen, C., Carney, K. and Swinton, S.M. (2007) Ecosystem Services and Dis-Services to Agriculture. Ecological Economics, 64, 253-260. http://dx.doi.org/10.1016/j.ecolecon.2007.02.024

[78] Armbrecht, I. and Gallego, M.C. (2007) Testing ant Predation on the Coffee Berry Borer in Shaded and Sun Coffee Plantations in Colombia. Entomologia Experimentalis et Applicata, 124, 261-267.

[79] Gallai, N., Salles, J.M., Settele, J. and Vaissière, B.E. (2009) Economic Valuation of the Vulnerability of World Agriculture Confronted with Pollinator Decline. Ecological Economics, 68, 810-821. http://dx.doi.org/10.1016/j.ecolecon.2008.06.014

[80] Potts, S.G., Biesmeijer, J.C., Kremen, C., Neumann, P., Schweiger, O. and Kunin, W.E. (2010) Global Pollinator Declines: Trends, Impacts and Drivers. Trends in Ecology \& Evolution, 25, 345-353. http://dx.doi.org/10.1016/j.tree.2010.01.007

[81] Tscharntke, T., Klein, A.M., Kruess, A., Steffan-Dewenter, I. and Thies, C. (2005) Landscape Perspectives on Agricultural Intensification and Biodiversity-Ecosystem Service Management. Ecology Letters, 8, 857-874. http://dx.doi.org/10.1111/j.1461-0248.2005.00782.x

[82] Moguel, P. and Toledo, V.M. (1999) Biodiversity Conservation in Traditional Coffee Systems of Mexico. Conservation Biology, 13, 11-21. http://dx.doi.org/10.1046/j.1523-1739.1999.97153.x

[83] Andrén, H. (1994) Effects of Habitat Fragmentation on Birds and Mammals in Landscapes with Different Proportions of Suitable Habitat: A Review. Oikos, 71, 355-366. http://dx.doi.org/10.2307/3545823

[84] Kuussaari, M., Bommarco, R., Heikkinen, R.K., Helm, A., Krauss, J., Lindborg, R., et al. (2009) Extinction Debt: A Challenge for Biodiversity Conservation. Trends in Ecology \& Evolution, 24, 564-571. http://dx.doi.org/10.1016/j.tree.2009.04.011

[85] Donald, P.F., Sanderson, F.J., Burfield, I.J. and Van Bommel, F.P. (2006) Further Evidence of Continent-Wide Impacts of Agricultural Intensification on European Farmland Birds, 1990-2000. Agriculture, Ecosystems \& Environment, 116, 189-196. http://dx.doi.org/10.1016/j.agee.2006.02.007

[86] Myers, N., Mittermeier, R.A., Mittermeier, C.G., Da Fonseca, G.A. and Kent, J. (2000) Biodiversity Hotspots for Conservation Priorities. Nature, 403, 853-858. http://dx.doi.org/10.1038/35002501

[87] Goulart, F.F., Salles, P. and Machado, R.B. (2013) How May Agricultural Matrix Intensification Affect Understory Birds in an Atlantic Forest Landscape? A Qualitative Model on Stochasticity and Immigration. Ecological Informatics, 18, 93-106. http://dx.doi.org/10.1016/j.ecoinf.2013.06.010

[88] Tubelis, D.P., Cowling, A. and Donnelly, C. (2004) Landscape Supplementation in Adjacent Savannas and Its Implications for the Design of Corridors for Forest Birds in the Central Cerrado, Brazil. Biological Conservation, 118, 353364. http://dx.doi.org/10.1016/j.biocon.2003.09.014

[89] Wright, H.L., Lake, I.R. and Dolman, P.M. (2012) Agriculture-A Key Element for Conservation in the Developing World. Conservation Letters, 5, 11-19. http://dx.doi.org/10.1111/j.1755-263X.2011.00208.x

[90] Dorrough, J., Ash, J. and McIntyre, S. (2004) Plant Responses to Livestock Grazing Frequency in an Australian Temperate Grassland. Ecography, 27, 798-810. http://dx.doi.org/10.1111/j.0906-7590.2004.04004.x

[91] Schulze, C.H., Waltert, M., Kessler, P.J., Pitopang, R., Veddeler, D., Mühlenberg, M., et al. (2004) Biodiversity Indicator Groups of Tropical Land-Use Systems: Comparing Plants, Birds, and Insects. Ecological Applications, 14, 13211333. http://dx.doi.org/10.1890/02-5409

[92] Harvey, C.A. and Villalobos, J.A.G. (2007) Agroforestry Systems Conserve Species-Rich but Modified Assemblages of Tropical Birds and Bats. Biodiversity and Conservation, 16, 2257-2292. 
http://dx.doi.org/10.1007/s10531-007-9194-2

[93] Steffan-Dewenter, I., Kessler, M., Barkmann, J., Bos, M.M., Buchori, D., Erasmi, S., et al. (2007) Tradeoffs between Income, Biodiversity, and Ecosystem Functioning during Tropical Rainforest Conversion and Agroforestry Intensification. Proceedings of the National Academy of Sciences of the United States of America, 104, 4973-4978.

http://dx.doi.org/10.1073/pnas.0608409104 